\title{
Molecular identification of cellulase and protease producing Bacillus tequilensis UTMSA14 isolated from the geothermal hot spring in Lau Sidebuk Debuk, North Sumatra, Indonesia
}

\author{
EDY FACHRIAL ${ }^{1}$, RADEN RORO JENNY SATYO PUTRI ${ }^{2}$, I NYOMAN EHRICH LISTER ${ }^{3}$, \\ SARI ANGGRAINI ${ }^{4}$, HARMILENI $^{5}$, TITANIA T. NUGROHO ${ }^{6}$, SARYONO $^{6, \varphi}$ \\ ${ }^{1}$ Laboratory of Molecular Biology, Faculty of Medicine, Universitas Prima Indonesia. Jl. Belanga No. 1, Medan 20118, North Sumatra, Indonesia \\ ${ }^{2}$ Graduate Program of Biomedical Sciences, Faculty of Medicine, Universitas Prima Indonesia. Jl. Belanga No. 1, Medan 20118, North Sumatra, Indonesia \\ ${ }^{3}$ Faculty of Medicine, Universitas Prima Indonesia. Jl. Belanga Simpang Ayahanda No. 1, Medan, North Sumatra, Indonesia \\ ${ }^{4}$ Faculty of Agrotechnology, Universitas Prima Indonesia. Jl. Gg. Madrasah, Sei Agul, Medan 20117, North Sumatra, Indonesia \\ ${ }^{5}$ Politeknik Teknologi Kimia Industri. Jl. Medan Tenggara No. 7, Medan 20228, North Sumatra, Indonesia \\ ${ }^{6}$ Department of Chemistry, Universitas Riau. Jl. Bina Widya Km 12,5, Simpang Baru, Pekanbaru 28293, Riau, Indonesia. \\ Tel. +62-761-63273, ‘email: saryono@lecturer.unri.ac.id
}

Manuscript received: 23 July 2020. Revision accepted: 22 September 2020.

\begin{abstract}
Fachrial E, Putri RRJS, Lister INE, Anggraini S, Harmileni, Nugroho TT, Saryono. 2020. Molecular identification of cellulase and protease producing Bacillus tequilensis UTMSA14 isolated from the geothermal hot spring in Lau Sidebuk Debuk, North Sumatra, Indonesia. Biodiversitas 21:4719-4725. The industrial need for stable microbial enzymes tends to increase every year. The aim of this study was to isolate and identify the protease and cellulase producing thermophilic bacteria isolated from the geothermal spring of Lau Sidebuk Debuk, North Sumatra, Indonesia. The protease activity was determined based on the formation of halo zone on Skim Milk Agar, while cellulase was confirmed using CMC plate agar method. Nine bacterial isolates were successfully obtained from the sediments and water, and both activities were observed in only one isolate, known as UTMSA14. These isolates were characterized biochemically and morphologically. The molecular identification of UTMSA14 was done by 16S rRNA sequencing based on BLAST and phylogenetic analysis using MEGA X. Phylogenetic analysis showed that UTMSA14 clustered together with Bacillus tequilensis strain 10b (accession number NR 104919.1), which ascertained the isolate as Bacillus tequilensis strain 10b (accession number NR 104919.1). This is the first report of a thermophilic bacteria isolated from Lau Sidebuk Debuk hot springs, with the ability to produce cellulase and protease. Further research is needed to purify and characterize the resulting enzymes, with a potential for industrial applications.
\end{abstract}

Keywords: Cellulase, geothermal hot springs, protease, thermophilic bacteria

\section{INTRODUCTION}

The thermophilic bacteria are those known to grow optimally between $50^{\circ} \mathrm{C}$ and $80^{\circ} \mathrm{C}$. Previous studies within the past two decades have reported on the under exploration of about $99 \%$ of microorganisms in this group. However, only a few have been cultivated in laboratories, causing optimization failures encountered in biotechnology and industrial application (Adhikari et al. 2015). Generally, microorganisms have been identified as the best source of enzymes, due to their ability to culture in large quantities, and within a relatively short time, alongside the higher stability, compared to plant and animal sources (Acharya and Chaudhary 2012).

Proteases refer to a large group of enzymes belonging to the class of hydrolase whose catalytic function is to hydrolyze peptide bonds of protein. Protease plays a very important role in industrial applications, especially in the aspect of food, leather, pharmaceutical, and detergent. They contribute to over $60 \%$ of the world's enzyme market. The limited amount of protease from plants and animals to meet the needs of proteases in the world led to increase interest in microbial protease (Kumar et al. 2016). Microbial-derived proteases are preferred over enzymes from plants and animals because these have the desired characteristic for biotechnological applications (Rani et al. 2012).

Cellulase is the third-largest industrial enzyme, due to the use in paper recycling, cotton processing, detergent, and also food processing (Alam et al. 2017). Cellulase is enzymes which hydrolyze the $\beta$-1,4-glycosidic linkage of cellulose and synthesized by microorganisms during their growth on cellulosic materials. Most of the cellulose degradation occurring in nature is brought by microorganisms including fungi and bacteria (Saranraj et al. 2012). Bacteria can be isolated from various types of environments on earth, and can produce cellulolytic strains that are extremely resistant to environmental stress. This includes thermophilic bacteria which can be found in environments with extreme temperatures such as hot springs and volcanoes (Almando et al. 2019). Enzymes produced by thermophilic bacteria are also stable against extreme conditions that may occur in the bioconversion process and this can also increase the level of enzymatic hydrolysis.

Indonesia is a country with several geothermal areas and at least 120 volcanic centers spread over volcanic belts (Aditiawati et al. 2009). North Sumatra is one of the 
provinces with numerous geothermal hot springs. In previous study, it was reported that keratinolytic bacteria of Penen, Semangat Gunung, and Sipoholon hot spring of North Sumatra Indonesia, were successfully isolated. Three isolates namely KW05, SQ04, and WR03 were chosen to characterize the enzyme activity. From these three isolates, isolate KW05 showed high keratinolytic activity (Suryanto et al. 2015). Another study on thermophilic bacterial reported that the bacteria isolated from Penen village hot springs showed that protease and carbohydrase activity. This bacteria identified as Bacillus subtilis JCM 1465 (Fachrial et al. 2019). please add previous relevant researches

Lau Sidebuk Debuk is a village that has hot springs with sulfur, this is due to its location at the foot of Sibayak volcano. Hot springs emerge through cracks from lava flows in the southern slopes of the Sibayak volcano. The research aims to isolate and identify the protease and cellulase producing thermophilic bacteria isolated from geothermal spring of Lau Sidebuk Debuk, North Sumatra, Indonesia

\section{MATERIALS AND METHODS}

\section{Sampling location}

Sampling was carried out at a location $70 \mathrm{~km}$ from the Medan city, North Sumatra, Indonesia within the coordinates $3^{\circ} 13^{\prime} 38^{\prime \prime} \mathrm{N}$ and $98^{\circ} 32^{\prime} 19^{\prime} \mathrm{E}$, and an altitude of $1.394 \mathrm{~m}$ asl., located in Semangat Gunung Village, Karo District, North Sumatra, Indonesia (Figure 1). This process was initiated by determining the $\mathrm{pH}$ and temperature of the several points around the hot springs, and then sample collected was performed three times. Table 1 shows the result of $\mathrm{pH}$ and temperature.

Hot water samples were collected from three points (Table 1), using a sterilized bottle. Approximately $100 \mathrm{~mL}$ water samples were taken and stored in a sterilized screw plastic tube, followed by the measurement of $\mathrm{pH}$ and temperature. Therefore, samples were stored in the icebox and transported to the laboratory as soon as possible for further analysis after collection.

\section{Screening of protease and cellulase producing microorganism}

Water samples $(1 \mathrm{~mL})$ from each sampling point were mixed and homogenized with a vortex, followed by the addition of $9 \mathrm{~mL}$ sterile Tryptic Soy Broth (TSB), and the mixture was subsequently incubated at $50^{\circ} \mathrm{C}$ for 24 hours. Furthermore, serial dilution of up to $10^{-3}$ was performed, and then $1 \mathrm{~mL}$ inoculum from the last dilution was spread on the surface of Tryptic Soy Agar (TSA), and incubated at $50^{\circ} \mathrm{C}$ for 48 hours. The observed bacterial colonies were purified by re-streaking onto the surface of TSA, and screening for protease activity was determined by inoculating on the surface of Skim Milk Agar (SMA). These were then incubated at $50^{\circ} \mathrm{C}$ for 48 hours, and the presence of halo zone around the colony indicated a positive outcome (Panda et al. 2013), while CMC plate assay was used to determine cellulase activity. Five microliters of overnight growth culture in nutrient broth was spot plated on CMC agar $(0.2 \%$ $\mathrm{NaNO}_{3}, 0.1 \% \quad \mathrm{~K}_{2} \mathrm{HPO}_{4}, 0.05 \% \quad \mathrm{MgSO}_{4}, 0.05 \% \mathrm{KCl}, 0.2 \%$ CMC sodium salt, $0.02 \%$ peptone and $1.7 \%$ agar). The plates were incubated at $50^{\circ} \mathrm{C}$ and then flooded with Gram's iodine solution for 5 minutes, the cellulase-producing isolates were detected by the cellulolytic zone around the colonies after Gram's iodine staining (Kasana et al. 2008)

Table 1. $\mathrm{pH}$ and temperature of the sampling site

\begin{tabular}{lcc}
\hline Sampling site & $\mathbf{p H}$ & Temperature $\left({ }^{\circ} \mathbf{C}\right)$ \\
\hline Site 1 & 6.5 & 50 \\
Site 2 & 6.1 & 51 \\
Site 3 & 6.2 & 50 \\
\hline
\end{tabular}

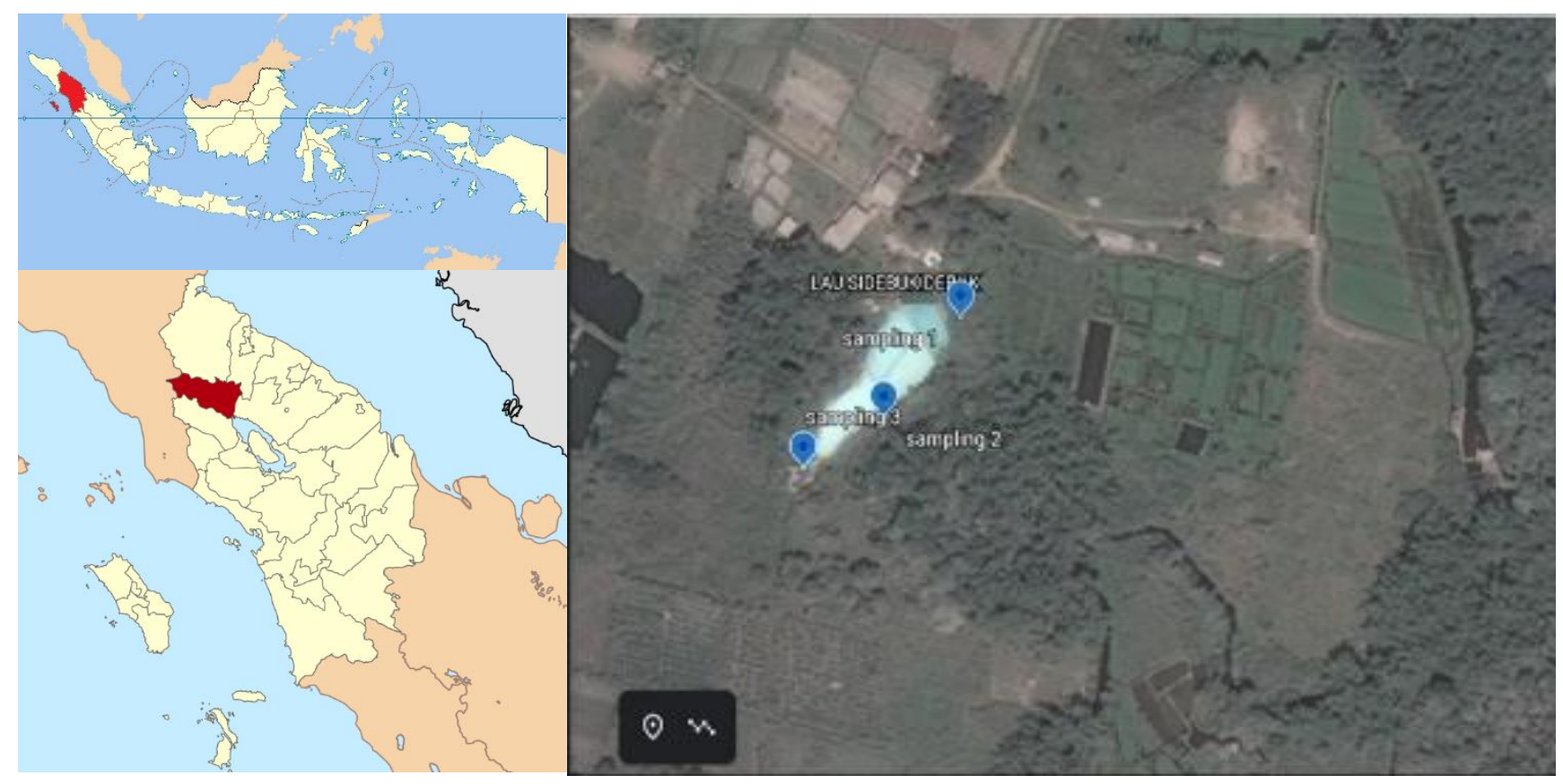

Figure 1. Sampling location on Lau Sidebuk Debuk, Semangat Gunung Village, Karo District, North Sumatra, Indonesia 


\section{Biochemical and morphological characterization}

UTMSA14 was further characterized biochemically and morphologically, using Gram staining, catalase and citrate test, gelatin hydrolysis, motility, and evaluation of shape, edge, color, and elevation. Gram staining was used to characterize UTMSA14 morphologically. Briefly, one loopful of isolate UTMSA14 was spread with inoculation loop to an even thin film over a circle of $1.5 \mathrm{~cm}$ in diameter. The culture was fixed over a gentle flame and crystal violet stain was added over the fixed culture. Let its stand for 60 seconds and pour off the excess stain with running water. The iodine solution was added on the smear and then the excess solution was poured off with running water. A few drops of decolorizer were added and rinse it off with running water after 5 seconds. The culture was counterstained with basic fuchsin solution for 60 seconds. The excess solution was washed off with running water. The slide was blotted with bibulous paper to remove the excess water and airdried. Morphological characterization was conducted using light microscope with $100 \times$ magnification (Claus 1992). The catalase test was carried out by dropping a few drops of $3 \%$ hydrogen peroxide onto the bacterial isolate on the surface of the slide. The appearance of air bubbles indicates a positive result (Reiner 2013). The citrate test was carried out by inoculating the Simmons citrate agar lightly on the slant by touching the tip of a needle to a colony that is $18-24$ hours old. The slant was incubated at $37^{\circ} \mathrm{C}$ for seven days and observe for growth and the development of blue color, indicating alkalinization. The growth on medium, with or without change in the color of indicator indicated positive results (MacWilliams 2009). The gelatin hydrolysis test was carried out according to nutrient gelatin stab method. The bacteria were inoculated by stabbing on the tube containing nutrient gelatin medium. The inoculated tube was incubated at $37^{\circ} \mathrm{C}$ for two weeks along with uninoculated medium. The tubes were removed daily from incubator and placed in ice bath or refrigerator every day to check for gelatin liquefaction. Partial of total liquefaction of the inoculated tube indicated positive results. The motility test was carried out by stabbing the inoculum into the center of a semisolid agar deep using a sterile inoculating needle. The presence of cloudiness in the medium indicating positive results ( dela Cruz and Torres 2012).

\section{DNA isolation, 16SrRNA amplification, and sequencing for molecular characterization}

Molecular identification of isolate was conducted using $16 \mathrm{~S}$ rRNA gene sequencing and analysis. Genomic DNA was initially extracted using Geneaid ${ }^{\mathrm{TM}}$ DNA isolation kit. As much as $1 \mu \mathrm{L}$ DNA template was mixed in $25 \mu \mathrm{L}$ PCR solution consisting $1 \mu \mathrm{L}$ forward primer, $1 \mu \mathrm{L}$ reverse primer, $12,5 \mu \mathrm{L}$ GoTaq Green Master Mix, $0.5 \mu \mathrm{L}$ DMSO and $9 \mu \mathrm{L}$ nuclease-free water. The primers used were $27 \mathrm{~F}$ : 5 - AGA GTT TGA TCC TGG CTC AG - 3`and 1492 R: 5 - GGT TAC CTT GTT ACG ACT T - 3` (Srinivasan et al. 2015). The PCR mixture was placed into a PCR machine with the following settings: initial denaturation of $96^{\circ} \mathrm{C}$ for 5 minutes, followed by 30 cycles of denaturation at $96^{\circ} \mathrm{C}$ for 30 seconds, annealing at $55^{\circ} \mathrm{C}$ for 30 seconds, and strand elongation at $72^{\circ} \mathrm{C}$ for 1 minute. After completing the 30 cycles, another round of elongation was performed on the final strand at $72^{\circ} \mathrm{C}$ for 7 minutes. The amplified PCR products were electrophoresed on an agarose gel (1.5\%) in TAE buffer, visualized by staining with Gel Red and analyzed by Gel Documentation. The amplification result was sequenced using automated DNA sequencer (ABI PRISM 3130 Genetic Analyzer to determine the sequence of DNA strands.

The raw data of the sequencing results were trimmed and assembled using the BioEdit program (http://www.mbio.ncsu.edu/BioEdit/bioedit.html). In order to determine the homologous taxon/species with the biggest and closest molecular similarity a BLAST search was done, data registered at GenBank, and the tools from NCBI/National Center for Biotechnology Information (http://www.ncbi.nlm.nih.gov/BLAST/). Phylogenetic analysis was done by first aligning sequences from the BLAST search with the 16S rRNA of UTMSA14 using clustalW, followed by phylogenetic analysis and tree generation using the program MEGAX (Kumar et al. 2018).

\section{RESULTS AND DISCUSSION}

\section{Isolation of protease and cellulase producing bacteria}

Total nine isolates were successfully identified in the present study, which showed protease or cellulase hydrolysis activity. However, only UTMSA14 exhibited both effects, evidenced by the formation of a clear zone around the colonies on Skim Milk Agar and Saboraud Dextrose Agar. These mediums were both supplemented with carboxymethyl cellulose and the UTMSA14 activities (Figure 2).

\section{Morphological and biochemical characterization}

The results of morphological and biochemical characterization of UTMSA14 are shown in Table 2 and Figure 3. Isolate UTMSA14 was determined as Grampositive bacteria (Table 2). This is indicated by the formation of blue-purple color in bacteria due to the crystal violet is retained in the thick peptidoglycan layer of cells. The analysis result under a light microscope showed that isolate UTMSA14 was a rod-shaped bacteria.

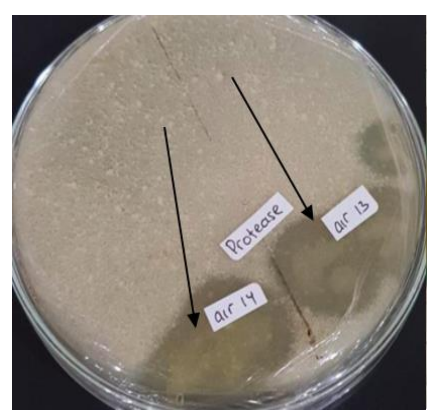

A

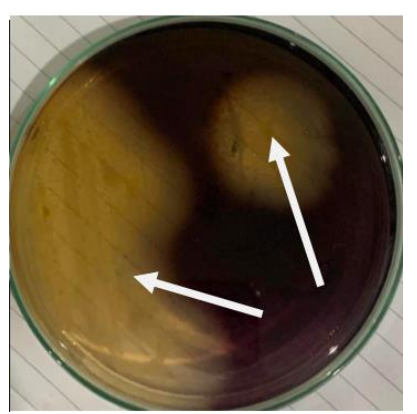

B
Figure 2. A. protease and B. cellulase activity of UTMSA14, indicated by the clear zone (pointed by the arrow) 


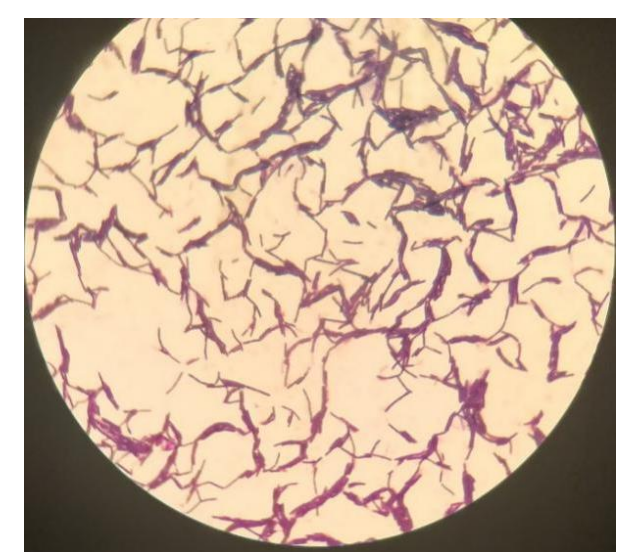

Figure 3. The morphology of UTMSA14 under a microscope with 1000x magnification, showing rod-shaped bacteria

Isolate UTMSA14 showed positive results in catalase test. This indicates that isolate UTMSA14 produced catalase enzyme which was able to breakdown hydrogen peroxide into oxygen and water. The positive result on citrate test showed that isolate UTMSA14 has the ability to utilize citrate as a source of energy. The isolate UTMSA14 also showed positive results on gelatin hydrolysis tests. Gelatin hydrolysis test is used to detect the ability of microorganism to produce gelatinase that liquefies gelatin. Hydrolysis of gelatin indicates the presence of gelatinases. Based on growth on sulfide indole motility medium, the isolate UTMSA14 was motile. Bacterial motility was evident by a diffuse growth extending out from the line of inoculation on sulfide indole motility medium.

\section{Molecular identification of UTMSA14}

The 16S rRNA sequence of UTMSA was $1400 \mathrm{bp}$ and has been deposited in GenBank with the accession number MT936336. The phylogenetic analysis of UTMSA14 was shown in Figure 4, showing that UTMSA14 clusters together with Bacillus tequilensis. Therefore, it concludes that UTMSA14 is B. tequilensis strain UTMSA14.

Bacillus tequilensis UTMSA14 showed similar characteristics to B. tequilensis $10 \mathrm{~b}$, namely Gram-positive, motile, produces catalase and gelatinase enzymes, and shows aggregates in form of chains. This strain also has an optimum growth at $50{ }^{\circ} \mathrm{C}$ at $\mathrm{pH}$ 6.5-8 (Reimer et al. 2019).

Table 2. Biochemical and morphological characteristics of UTMSA14

\begin{tabular}{ll}
\hline Characteristic & Result \\
\hline Gram staining & Positive \\
Catalase test & + \\
Citrate test & + \\
Gelatin hydrolysis & + \\
Motility & Motile \\
& \\
Shape & Circular \\
Edge & Entire \\
Color & Cream \\
Elevation & Flat \\
\hline
\end{tabular}

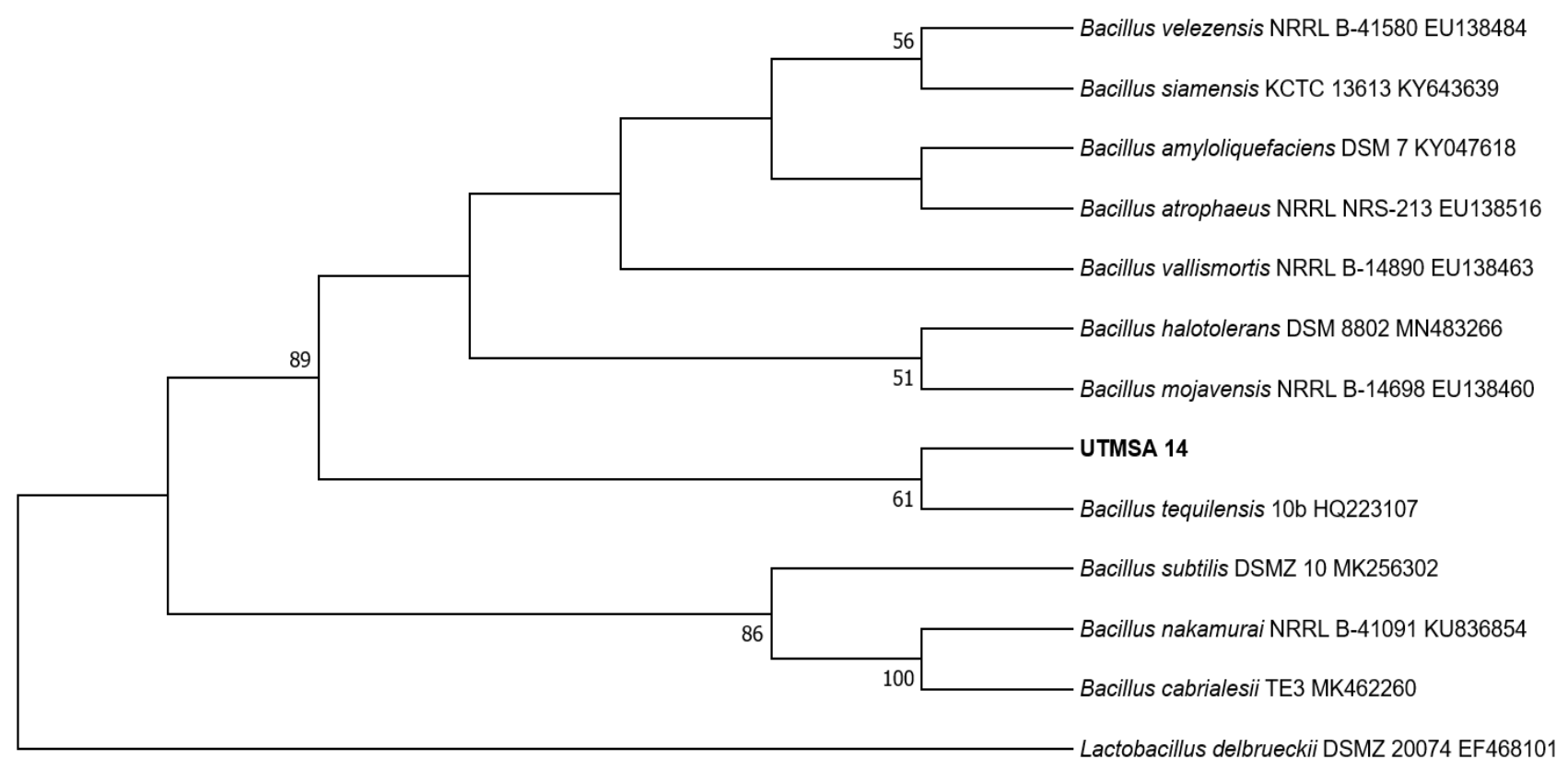

Figure 4. Phylogenetic analysis of UTMSA14. The phylogenetic tree was constructed by the Neighbour-Joining methods with 1000 replications. The evolutionary distances were computed using the p-distance method with pairwise deletion. Lactobacillus delbruecki DSMZ 20074 was used as an outgroup 


\section{Discussion}

The source of heat is from the lava flow within the southern slope of the Sibayak volcano (Sinulingga et al. 2019), making it a potential site for the isolation of thermophilic bacteria. This is due to the environmental conditions, supported by biotic and abiotic factors (Agustina et al. 2019), as the composition and permeability of fatty acyl ester lipid membrane is highly dependent on phase transition temperature. These changes are quickly regulated, and the G-C content of the inherent rRNA and tRNA molecules are relatively higher, when compared to mesophiles. Hence, more hydrogen bonds are formed, in contrast with the AT base pair, which further improves RNA thermostability (Mehta et al. 2016).

The result of $\mathrm{pH}$ measurement was 6.1-6.5 (Table 1), which allows for optimal growth of thermophilic bacteria. Based on acidity or alkalinity, hot springs are generally classified into six classes, including: strong acid spring $(\mathrm{pH}$ $<2)$, acid spring $(2 \leqq \mathrm{pH} \leqq 4)$, weak acid spring $(4 \leq \mathrm{pH} \leq$ $6)$, neutral spring $(6 \leq \mathrm{pH} \leq 7.5)$ weak alkaline spring $(7.5 \leq$ $\mathrm{pH} \leq 9)$ and alkaline spring $(\mathrm{pH} \geq 9)$ (Simon et al. 2019). This categorization is in line with the study of Ifandi and Alwi (2018), which reported on the optimum growth of thermophilic bacteria isolated from Bora Hot Springs in Central Sulawesi, at $\mathrm{pH}$ 6-8, indicating neutrophilic to alkalophilicity. Previous research also reported on the production of thermostable enzymes from Bacillus licheniformis, present in the Jordanian springs with neutral pH (7.03) (Mohammad et al. 2017). Similar results were also reported by Aqel et al. (2012), in which the Bacillus strain HUTBS62 isolated from hot spring near Dead Sea, Jordan, which has neutral $\mathrm{pH}$, has optimum catalytic activity of protease at $\mathrm{pH}$ 6.8. Meanwhile, the protease activity of UTMSA14 was indicated by the clear zone formed on the surface of skimmed milk agar media. Similar study carried out by Abdalla et al. (2016) also indicated the formation of clear zone as indicator of protease activity which may be due to the microbial hydrolysis of casein.

In another study it was reported that bacteria are the most important protease-producing group, especially from the genus Bacillus. This is due to the high level of enzyme secretion, in which some species of Bacillus produce more than $20 \mathrm{~g} / \mathrm{L}$ protein. In addition, some Bacillus species produce alkaline and neutral proteases suitable for use in industry. Several extracellular proteases produced by Bacillus are serine, cysteine and metalloprotease, with molecular weights ranging from 27-71 kDa (Contesini et al. 2018). B. tequilensis is a potential candidate for use in industry especially the detergent industry. In a previous study, it was reported that B. tequilensis MTCC 9585 isolated from agriculture soil produced protease in only 6 hours of incubation and had a wide range of protease activities ranging from $\mathrm{pH} 5$ to 12 , and temperature ranges from $25^{\circ} \mathrm{C}$ to $50^{\circ} \mathrm{C}$. The protease also has optimum activities at $60^{\circ} \mathrm{C}$ and stable at storage period of 270 days at $10^{\circ} \mathrm{C}$ (Khan et al. 2011). Previous studies identified the thermophilic bacteria isolated from desert soils in Tharparkar, Pakistan, as B. tequilensis strain ZMS-2, which is known to produce alkaline protease under optimum conditions of $\mathrm{pH} 8$ and temperature $60{ }^{\circ} \mathrm{C}$. This strain was reported to have antimicrobial activity also (Khan et al. 2019).

Naturally, fungi produce more cellulase activity than bacteria, which generates a relatively better catalyst, because of the reduced feedback inhibition encounters, but bacteria grow relatively faster, with the enzyme having higher activity against crystalline cellulose, including cotton and avicel, and better stability towards heat and alkaline $\mathrm{pH}$, compared with fungi (Acharya and Chaudhary 2012). Fungi also have a lower reaction rate than bacterial enzymes, and among bacteria, Bacillus spp. is attractive industrial tools for a source of protease enzyme including leather industries, Bacillus licheniformis $\mathrm{N}-2, B$. cereus strain AT and $B$. amyloliquefaciens produce protease that is used in detergent, tannery, and food industries respectively (Hamza 2017).

The isolation and characterization of cellulase producing bacteria are now becoming widely exploited. There are several reasons for these shifts, including (i) bacteria have a higher growth rate than fungi, allowing for higher production level of cellulase, (ii) cellulase produced by bacteria has a more complex and multi-enzyme complexes which providing increase function and energy, (iii) several strains of bacteria can grow in environment with extreme $\mathrm{pH}$ and temperature (Imran et al. 2016). This strain can survive and produce cellulase enzymes that can be used in the bioconversion process. Bacillus sp. is one of the bacteria producing the type of cellulase i.e. endoglucanase. Endoglucanase cut at a random at internal amorphous sites in the cellulose polysaccharide chain, generating oligosaccharides of various lengths. It is generally active against acid-swollen amorphous cellulose, soluble derivatives of cellulose such as CMC (Sangrila and Tushar 2013). This study showed that Bacillus as cellulase producer lag far behind compared to cellulase-producing fungi. This is due to most of Bacillus cellulase hydrolyze synthetic cellulase (Carboxymethyl cellulase), but almost does not hydrolyze the crystalline form of cellulose. In a previous study, it was reported that bacteria identified as Bacillus and Paenibacillus from soil sample in Thailand, showed cellulase activity which was characterized by clear zones around colonies growing on CMC media with clear zone diameters ranging from 0.6 to $2.95 \mathrm{~cm}$ (Akaracharanya et al. 2014).

Meanwhile, another research reported on the isolation of B. tequilensis strain GYLH001 from Angelica dahurica, which is capable of producing cellulase, protease, and gelatinase enzymes. These enzymes demonstrate stable activity after heat treatment at $100^{\circ} \mathrm{C}$ for 30 minutes ( $\mathrm{Li}$ et al. 2018). The cellulase activity of isolate UTMSA14 was indicated by the formation of a clear zone on CMC agar surface, resulting from the reaction between congo red and bonding $\beta$-1,4-glycosidic contained in the cellulose polymer, leading to microbial hydrolysis (Missa et al. 2016), although Bacillus is known as one of the bacterial species used as a source of protease. This is due to the chemoorganotropic characteristics, rapid growth, extracellular enzyme secretion to the media, and ease of culture (Saggu and Mishra 2017). 
The phylogenetic tree was constructed from 10 isolates using neighbor-joining method with 1000 replications. the following strains were identified from isolate UTMSA14: Bacillus velezensis, B. siamensis, B. amyloliquofaciens, $B$. vallismortis, B. halotolerans, B. mojavensis, B. tequilensis, B. subtilis, B. nakamurai, and B. cabrialesii. Lactobacillus delbrueckii was used as an outgroup. The optimal tree with sum branch of length 0.83124795 is shown. The evolutionary distances were computed using the p-distance method with pairwise deletion. Based on phylogenetic analysis, UTMSA14 has closest evolutionary correlation with $B$. tequilensis when compared to B. subtilis. In previous study, it was reported that $\mathrm{B}$. tequilensis (VCB1, VCB2, and VSDB4) was isolated from hot springs of Manikaran, Kalath, and Vasist of Himachal Pradesh. B.tequilensis VCB1 showed cellulolytic activity, meanwhile highest exoglucanase activity was observed in B. tequilensis VSDB4 (Thankappan et al. 2018).

In conclusion, in this study, we isolate the thermophilic bacteria from Lau Sidebuk Debuk hot springs which showed protease and cellulase activity, known as UTMSA14. The molecular identification and phylogenetic analysis showed that UTMSA14 cluster together with $B$. tequilensis, therefore, it concludes that UTMSA14 is B. tequilensis strain UTMSA14. Therefore, it is necessary to carry out further research to investigate the isolation, activity, and characterization of thermostable enzyme produced by $B$. tequilensis UTMSA14, with potential for industrial applications.

\section{ACKNOWLEDGEMENTS}

This study was supported by Republic of Indonesian Ministry of Research and Technology/National Research and Innovation Agency through Collegiate Research Collaboration Grant between Universitas Prima Indonesia and Universitas Riau, Indonesia with contract number: 222/LL1/PG/2020.

\section{REFERENCES}

Abdalla MS, Seoudi OA, Salem AA, Hasan EAI. 2016. Isolation, screening, production of extracellular protease from thermophilic bacteria. Egypt J Appl Sci 31 (2): 1-16.

Acharya S, Chaudhary A. 2012. Bioprospecting thermophiles for cellulase production: a review. Brazilian J Microbiol 43 (3): 844-56. DOI: 10.1590/S1517-83822012000300001

Adhikari H, Ghimire S, Khatri B, Yuvraj KC. 2015. Enzymatic screening and molecular characterization of thermophilic bacterial strains isolated from hotspring of Tatopani, Bhurung, Nepal. International J Appl Sci Biotechnol 3 (3): 392-97. DOI: 10.3126/ijasbt.v3i3.12724.

Aditiawati P, Yohandini H, Madayanti F, Akhmaloka. 2009. Microbial diversity of acidic hot spring (Kawah Hujan B) in Geothermal Field of Kamojang Area, West Java-Indonesia. The Open Microbiol Journal 3 (1): 58-66. DOI: 10.2174/1874285800903010058.

Agustina W, Rahman T, Ratnawati L, Sriharti, Salim T, Nursyahbani I.. 2019. Potential Isolates Characterization of Thermophilic Bacteria from Hot Springs and Waste Agricultural Production in Subang District Area. IOP Conference Series: Earth and Environmental Science 251 (1): 1-7. DOI: 10.1088/1755-1315/251/1/012006.

Akaracharanya A, Taprig T, Sitdhipol J, Tanasupawat S. 2014 Characterization of cellulase producing Bacillus and Paenibacillus
Strains from Thai Soils. J Applied Pharmaceutical Science 4 (5): 6-11. DOI: 10.7324/JAPS.2014.40502.

Alam Md. G, Ekhlas Uddin Md, Rahman S, Reazul Karim M, Sharifull Islam Md, Ahamad T, Jakir Hossain Md, et al. 2017. Protease Activity of Extracellular Enzyme Produced by B. subtilis Isolated from Soil. International J Environment, Agriculture and Biotechnol 2 (1): 382-88. DOI: $10.22161 /$ ijeab/2.1.48.

Almando AG, Wanguyun AP, Hariyanto S. 2019. Bioprospecting Thermostable Enzymes-Producing Thermophiles from Indonesia. Ecol, Environment and Conservation 25 (7): S75-79.

Aqel H, Al-quadan F, Yousef TK. 2012. A Novel Neutral Protease from Thermophilic Bacillus Strain HUTBS62. J BioSci Biotech. 1 (2): 117 23.

Br. Sinulingga EK, Humaizi H, Lubis Z. 2019. The Role of Community Participation in the Development of Lau Debuk-Debuk Hot Spring in Doulu Village, Karo Regency. International $\mathrm{J}$ Multicultural and $\begin{array}{lllll}\text { Multireligious } & \text { Understanding } 6 & (5): & 16 . & \text { DOI: }\end{array}$ 10.18415/ijmmu.v6i5.1021.

Claus D. 1992. A Standardized Gram Staining Procedures. World J Microbiol Biotechnol 8: 451-52.

Contesini FJ, de Melo RR, Sato HH. 2018. An Overview of Bacillus Proteases: From Production to Application. Critical Reviews in Biotechnol 38 (3): 321-34. DOI: 10.1080/07388551.2017.1354354.

dela Cruz TEE, Torres JMO. 2012. Gelatin hydrolysis test protocol. American Society for http://www.asmscience.org/content/education/protocol/protocol.3776.

Fachrial E, Anggraini S, Harmileni, Nugroho TT, Saryono. 2019. Isolation and molecular identification of carbohydrase and protease producing Bacillus subtilis JCM 1465 isolated from Penen Hot Springs in North Sumatra, Indonesia. Biodiversitas 20 (12): 3493-98. DOI: 10.13057/biodiv/d201205.

Hamza TA. 2017. Bacterial protease enzyme: safe and good alternative for industrial and commercial use. Intl J Chem Biomol Sci 3 (1): 1-10.

Ifandi S, Alwi M. 2018. Isolation of Thermophilic Bacteria from Bora Hot Springs in Central Sulawesi. Biosaintifika J Biol Biol Educat 10 (2): 291-297.

Imran M, Anwar Z, Irshad M, Asad MJ, Ashfaq H. 2016. Cellulase production from species of fungi and bacteria from agricultural wastes and its utilization in industry: a review. Adv Enzyme Res 4 (2): 44-55. DOI: 10.4236/aer.2016.42005.

Kasana RC, Salwan R, Dhar H, Dutt S, Gulati A. 2008. A rapid and easy method for the detection of microbial cellulases on agar plates using Gram's Iodine. Curr Microbiol 57 (5): 503-7. DOI: 10.1007/s00284008-9276-8.

Khan I, Puja G, Jyoti V. 2011. Thermo-alkaliphilic halotolerant detergent compatible protease(s) of Bacillus tequilensis MTCC 9585. Afr J Microbiol Research 5 (23): 3968-75. DOI: 10.5897/ajmr11.705.

Khan Z, Shafique M, Nawaz HR, Jabeen N, Naz SA. 2019. Bacillus tequilensis ZMS-2: A novel source of alkaline protease with antimicrobial, anti-coagulant, fibrinolytic and dehairing potentials. Pakistan J Pharmaceut Sci 32 (4): 1913-18.

Kumar NS, Devi S, Nair AS. 2016. A Review on Microbial Proteases. Intl J Adv Res 4 (4): 144-49. DOI: 10.21474/IJAR01.

Kumar S, Stecher G, Li M, Knyaz C, Tamura K. 2018. MEGA X: Molecular Evolutionary Genetics Analysis across computing platforms. Mol Biol Evol 35 (6): 1547-1549.

Li H, Guan Y, Dong Y, Zhao L, Rong S, Chen W, Li M, et al. 2018. Isolation and evaluation of endophytic Bacillus tequilensis GYLH001 with potential application for biological control of Magnaporthe oryzae. PLoS ONE 13 (10): e0203505. DOI: 10.1371/journal.pone.0203505.

MacWilliams M. 2009. Citrate Test. American Society for Microbiology. 2009.

http://www.asmscience.org/docserver/fulltext/education/protocol/prot ocol.3203.

Mehta R, Singhal P, Singh H, Damle D, Sharma AK. 2016. Insight into thermophiles and their wide-spectrum applications. 3 Biotech 6 (1): 1 9. DOI: $10.1007 / \mathrm{s} 13205-016-0368-\mathrm{z}$.

Missa H, Susilowati A, Setyaningsih R. 2016. Diversity and phylogenetic relationship of cellulolytic bacteria from the feces of Bali Cattle in South Central Timor, East Nusa Tenggara, Indonesia. Biodiversitas 17 (2): 614-19. DOI: 10.13057/biodiv/d170232.

Mohammad BT, Al Daghistani HI, Jaouani A, Abdel-Latif S, Kennes C. 2017. Isolation and characterization of thermophilic bacteria from Jordanian Hot Springs: Bacillus licheniformis and Thermomonas 
hydrothermalis isolates as potential producers of thermostable enzymes. Intl J Microbiol 2017: 1-12. DOI: 10.1155/2017/6943952.

Panda MK, Sahu MK, Tayung K. 2013. Isolation and characterization of a thermophilic Bacillus sp. with protease activity isolated from Hot Spring of Tarabalo, Odisha, India. Iranian J Microbiol 5 (2): 159-65.

Rani K, Rana R, Datt S. 2012. Review on latest overview of proteases. Int J Curr Life Sci 2 (1): 12-18.

Reimer LC, Vetcininova A, Carbasse JS, Söhngen C, Gleim D, Ebeling C, Overmann J. 2019. BacDive in 2019: Bacterial phenotypic data for high-throughput biodiversity analysis. Nucleic Acids Res 47 (D1) D631-36. DOI: 10.1093/nar/gky879.

Reiner K. 2013. Catalase Test Protocol. 2013 http://www.microbelibrary.org/library/laboratory-test/3226-catalasetest-protocol.

Saggu SK, Mishra PC. 2017. Characterization of thermostable alkaline proteases from Bacillus infantis SKS1 isolated from garden soil. PLoS ONE 12 (11): e0188724. DOI: 10.1371/journal.pone.0188724.

Sangrila S, Tushar KM. 2013. Cellulase production by bacteria : a review. Br Microbiol Res J 3 (3): 235-58.
Saranraj P, Stella D, Reetha D. 2012. Microbial cellulases and its applications: a review. Intl J Biochem Biotech Sci 1 (1): 1-12.

Simon N, Unjah T, Yusry M, Dzulkafli MA. 2019. Physico-chemical characterisation and potential health benefit of the Hulu Langat Hot Spring in Selangor, Malaysia. Sains Malaysiana 48 (11): 2451-62. DOI: 10.17576/jsm-2019-4811-15.

Srinivasan R, Karaoz U, Volegova M, MacKichan J, Kato-Maeda M, Miller S, Nadarajan R, Brodie EL, Lynch SV. 2015. Use of 16S RRNA gene for identification of a broad range of clinically relevant bacterial $\begin{array}{lllll}\text { pathogens. PLoS ONE } 10 & \text { (2): 1-22. DOI: }\end{array}$ 10.1371/journal.pone.0117617.

Suryanto D, Warsito K, Munir E, Nasution SK. 2015. Partial Characterization of Keratinase of Thermophilic Bacteria from Three Hotsprings of North Sumatra. Intl J ChemTech Res 7 (5): 2514-19.

Thankappan S, Kandasamy S, Joshi B, Sorokina KN, Taran OP, Uthandi S. 2018. Bioprospecting thermophilic glycosyl hydrolases, from hot springs of Himachal Pradesh, for biomass valorization. AMB Express 8 (1): 1-15. DOI: 10.1186/s13568-018-0690-4 